Tersedia Secara Online di

http://ojs.unik-kediri.ac.id/index.php/jurmateks/index

\section{JURMATEKS} http://dx.doi.oro/10.30737/jurmateks

\title{
Pengaruh Kombinasi Renolith Terhadap Stabilitas Tanah Pada Jalan Demuk Pucanglaban Tulungagung
}

\author{
Hermawan $^{1 *}$, A. I. Candra ${ }^{2}$, Y. C. S. Poernomo ${ }^{3}$. \\ ${ }^{1 * 2,3}$ Fakultas Teknik, Universitas Kadiri. \\ email : ${ }^{1 *}$ hermawan.elangjawa@gmail.com
}

\begin{tabular}{ll} 
A R T I C L E & I N F O \\
\hline Article history: & \\
Artikel masuk & $: 05-10-2020$ \\
Artikel revisi & $: 08-10-2020$ \\
Artikel diterima & $: 12-10-2020$ \\
\hline
\end{tabular}

Keywords :

Montmorillonite, Renolith, Soil, Stability.

\begin{abstract}
Style IEEE dalam mensitasi artikel ini:

[3]

S. Schlecht-Pietsch, U. Wagner, and

T. H. Anderson, "Changes in composition of soil polysaccharides and aggregate stability after carbon amendments to different textured soils, ” Appl. Soil Ecol., vol. 1, no. 2, pp. 145-154, 1994.
\end{abstract}

\begin{abstract}
A B S T RACT
The soil structure consists of several mineral composition elements, namely clay, sand, and other minerals, such as rocks. Montmorillonite soil structures are soil structures that are mostly clays inside their components. The nature of montmorillonitetype soils is prone to deflection when loading when there is a change in the level of water dehydration. In the preparation of the following final project, the author tries to correlate the effect of the Renolith combination on soil stability. Clay material is from the location of Jalan Demuk, Pucanglaban Village, Tulungagung Regency. The combination of additives used as a correlation of soil stability is Renolith, with 0\% (original soil), $5 \%, 10 \%, 15 \%$, and $20 \%$. The test method used is the method of soil classification, soil consistency limits, and soil compaction. The test results show that the original soil structure has montmorillonite activity value. In testing specimens with variations in the maximum combination (20\%) of soil structure material and Renolith, The original soil Proctor testing 6.72 $\mathrm{gr} / \mathrm{cm}^{3}$ and after combined with $20 \%$ Renolith increased to 10.56 $\mathrm{gr} / \mathrm{cm}^{3}$.
\end{abstract}

\section{A B S T R A K}

Struktur tanah terdiri dari beberapa unsur mineral penyusunannya, yaitu lempung, pasir dan mineral lain seperti batuan. struktur tanah bersifat monmorillonite adalah struktur tanah yang sebagian besar terdapat lempung didalam komponennya. Sifat dari tanah berjenis montmorillonite mudah mengalami lendutan ketika dilakukan pembebanan saat terjadi perubahan tingkat dehidrasi air. Pada penelitian ini diteliti korelasi pengaruh kombinasi renolith terhadap stabilitas tanah. Material tanah lempung diambil dari lokasi Jalan Demuk, Desa Pucanglaban, Kabupaten Tulungagung. Kombinasi bahan aditif yang digunakan sebagai korelasi stabilitas tanah adalah renolith dengan persentase jumlah $0 \%$ (tanah asli), 5\%, 10\%, 15\% dan $20 \%$. Metode pengujian yang digunakan adalah metode pemadatan tanah. Hasil pengujian benda uji menunjukkan bahwa struktur tanah asli dikategorikan memiliki nilai aktivitas montmorillonite. Pada pengujian benda dengan variasi kombinasi maksimal (20\%) bahan struktur tanah dan renolith, nilai proctor tanah asli $6,72 \mathrm{gr} / \mathrm{cm}^{3}$ dan setelah dikombinasikan dengan $20 \%$ renolith meningkat $10,56 \mathrm{gr} / \mathrm{cm}^{3}$. 


\section{Pendahuluan}

Tanah berfungsi sebagai perletakan dari sebuah konstruksi bangunan [1]. Sebuah bangunan harus memiliki keamanan yang ditentukan dari kekuatan strukturnya, baik struktur atas (upper structure) bangunan maupun struktur bawah (base structure) bangunan. Maksud dari struktur bawah bangunan ialah bangunan yang sebagian tertanam dibawah permukaan tanah, [2][3], dan digunakan sebagai media pemikul beban atas yang diteruskan melalui kolom dan kemudian disalurkan pada lapisan tanah keras,[4] [5][6]. Montmorillonite smectite adalah sebuah mineral yang terbentuk dari satu lembar aluminium (gibbsite) dan dua lembar silika. Sifat mekanis lempung montmorillonite ialah apabila lempung terkena air [1], maka dimensinya akan membesar sesuai dengan kapasitas penyerapan air itu sendiri, akan tetapi apabila lempung itu kering, dimensipun akan kembali mengecil seperti awal dengan wujud pemadatan yang tidak terarah, sehingga menyebabkan struktur tanah yang mengalami pembebanan akan berlendut apabila terjadi perubahan tingkat dehidrasi air. Pada penelitian ini bertujuan untuk meneliti korelasi pengaruh kombinasi renolith terhadap stabilitas tanah. Material yang dipergunakan adalah kombinasi bahan additif berupa renolith dengan sebagian besar struktur tanah pada lokasi adalah lempung. Perubahan kadar air pada struktur tanah lempung dapat mempengaruhi nilai konsistensi yang rendah. Hal tersebut ditunjukkan pada penelitian A. Susanto, tentang stabilisasi tanah dengan aspal emulsi yang menyebutkan bahwa tanah lempung memiliki sifat plastis pada kadar air sedang tetapi jika lempung dalam keadaan kering maka strukturnya akan keras dan sulit dikelupas oleh tangan [7]. Dengan demikian upaya dalam stabilisasi tanah sangat mutlak diperlukan dalam setiap aspek perencanaan pembangunan infrastruktur. Renolith merupakan bahan additif yang biasa dipergunakan sebagai material dalam melakukan perbaikan nilai stabilitas permukaan tanah lempung. Renolith merupakan bahan modifikasi yang mampu bersenyawa dengan air memiliki karakteristik mirip susu dan tersusun dari karet polimer selulosa [8]. Renolith bertujuan untuk mengunci partikel air tanah dan mempermudah proses dehidrasi struktur tanah lempung, sehingga bisa digunakan sebagai material dalam upaya melakukan perbaikan nilai stabilitas tanah. Dalam penelitian ini yang berjudul pengaruh kombinasi renolith terhadap stabilitas tanah pada Jalan Demuk Pucanglaban Tulungagung, dilakukan uji klasifikasi tanah, batas konsistensi tanah dan pemadatan tanah.

\section{Tinjauan Pustaka}

\subsection{Tanah}

Tanah berasal dari media yang tidak tersementasi secara kimia antara satu media dengan media lain dan berasal dari pelapukan bahan organik padat serta zat cair dan juga gas 
yang dapat mengisi pori - pori partikel padat tanah, [9]. Tanah berkohesif adalah tanah yang karakter fisiknya selalu mendapat tingkat pembasahan dan pengeringan yang menyusun butiran tanah sehingga memerlukan tenaga ekstra untuk memisahkan dalam keadaan kering, contoh lempung. Tanah tak berkohesif adalah butiran tanah terlapis yang sudah dikeringkan dan hanya melekat dalam keadaan basah, contohnya tanah berpasir, [10].

\subsection{Tanah Lempung}

Tanah Lempung merupakan, partikel tanah berukuran mikroskopik hingga submikroskopik dan berasal dari pelapukan bebatuan[11]. Partikel lempung hampir selalu terhidrasi atau dikelilingi lapisan-lapisan air terabsorbsi. Lapisan ini umumnya disebut sebagai lapisan difusi. Daya ikatnya dengan air cukup kuat sehingga sifatnya lebih padat dari benda yang berwujud cair [12]. Lempung memiliki beberapa sifat yang membuatnya berbeda dengan tanah lain yaitu butirannya halus (kurang dari 0,002 mm), permeabilitas rendah, kenaikan kapiler air tinggi, bersifat sangat kohesif, serta proses konsolidasinya bersifat lambat,[13] [14].

Kerr (1959) dalam Hardiyatmo (1992) [15][16] menyatakan bahwa, Lempung umumnya memiliki sekitar 15 macam mineral, diantaranya terdiri dari 3 komponen penting yaitu montmorillonite, lillite, dan kaolinite. Mineral ini, memiliki luas permukaan lebih besar dan mudah menyerap air lebih banyak dibanding mineral lainnya, sehingga tanah yang memiliki tingkat kepekaan terhadap pengaruh air sangat mudah mengembang, [17].

Dari berbagai studi akhir mengenai lempung dengan mempergunakan alat scanning electron microscope (SEM) memperlihatkan bahwa masing - masing partikel berkelompok atau berfokulasi bersama-sama dalam suatu satuan struktur sub-mikroskopis yang disebut dengan domain, hal ini ditunjukkan oleh berbagai peneliti, [18][19].

\subsection{Tanah Ekspansif}

Tanah Ekspansif merupakan suatu gambaran untuk sifat fisik dari tanah. Tanah ekspansif merupakan wujud dari suatu struktur tanah yang memiliki tingkat konsitensi rendah [20][21]. Tanah ekspansif adalah tanah yang volumenya mengalami perubahan disebabkan oleh perubahan kadar air didalam pori-pori tanah. Jika kadar air dalam tanah meningkat maka volume tanah akan mengembang, sebaliknya jika kadar air tanah berkurang maka tanah akan menyusut, sedangkan tanah ekspansif akan mengembang dan memberikan tekanan yang berdampak rusaknya konstruksi diatasnya jika terjadi adanya perubahan kadar air [22][23]. Pada umumnya komposisi tanah itu berisi lebih dari satu macam, semisal adalah clay, silt, 
sand dll. Tanah menjadi ekspansif apabila lempung (clay) banyak mengandung mineral montmorilonite, [24][25].

\subsection{Renolith}

Renolith merupakan bahan modifikasi yang mampu bersenyawa dengan air memiliki karakteristik mirip susu dan tersusun dari karet polimer selulosa. Secara garis besar bahan kimia ini berfungsi untuk mengatur kadar air tanah secara konsisten, sehingga tanah tidak mudah untuk berubah volume. [26][27] kadar campuran dan waktu fermentasi memiliki pengaruh besar terhadap nilai daya dukung tanah, Semakin tinggi kadar campuran renolith dan semakin lama waktu fermentasi maka dapat meningkatkan daya dukung tanah secara signifikan dibandingkan dengan tanah asli.

\subsection{Air}

Air merupakan substansi kimia dengan rumus $\mathrm{H} 2 \mathrm{O}$, sebuah molekul air tersusun dari 2 atom hidrogen dan satu atom Oksigen [28]. Pada penelitian ini, air digunakan sebagai media pelarut benda uji diambil langsung dari saluran air bersih pada Laboratorium Teknik Sipil Universitas Kadiri.

\subsection{Analisis Data}

Analisis data yang digunakan dalam pengujian stabilitas tanah yang telah ditambahkan bahan additif renolith adalah dengan melakukan pengujian karakteristik tanah asli dan melakukan komparasi hasil dari pengujian berat isi dan pemadatan tanah (Proctor).

\section{Metode Penelitian}

Metode pengujian yang dilaksanakan adalah dengan melakukan pengujian Gradasi Butiran dan pengujian Proctor dengan melakukan uji berat isi (Specific Gravity) dan pemadatan tanah, menggunakan benda uji tanah dari lokasi Jalan Demuk, Pucang Laban, Kabupaten Tulungagung yang dikombinasikan dengan bahan Additif Renolith sejumlah 5\%, 10\%,15\% dan 20\%. Adapun langkah - langkah dari pengujian akan dibahas dalam sub bab berikut.

\subsection{Pengujian Gradasi Butiran.}

Uji Gradasi Butiran dimaksudkan untuk mengetahui partikel-partikel penyusun suatu struktur tanah [29], uji berikut secara berkelanjutan akan dipergunakan sebagai tolak ukur klasifikasi tanah tersebut. Adapun langkah - langkah penelitian sebagai berikut :

1. Keringkan Struktur Tanah Asli.

Pengaruh Kombinasi Renolith Terhadap Stabilitas Tanah Pada Jalan Demuk Pucanglaban Tulungagung 
2. Ambil sampel tanah secara acak sebanyak $1000 \mathrm{gr}$.

3. Gunakan Gradasi Ayakan ukuran $256 \mathrm{~mm}-0,0625 \mathrm{~mm}$.

4. Letakkan Gradasi ayakan pada mesin penggoyang secara bertahap menganut ukuran dari yang terbesar.

5. Hitung berat tertahan pada setiap ayakan menggunakan timbangan dengan ketelitian hingga 1 gr.

6. Pada struktur tanah lolos ayakan ukuran $0,0625 \mathrm{~mm}$ gunakan alat Hydrometer $151 \mathrm{H}$.

7. Timbang dan masukkan struktur tanah lolos ayakan ukuran 0,0625 kedalam gelas ukur.

8. Isi dengan air suling dengan ukuran tertentu.

9. Diamkan hingga 120 menit / penelitian.

10. Masukkan Hydrometer kedalam gelas ukur.

11. Catat selisih angka kedalaman dengan ambangan Hydrometer.

12. Hitung Hasilnya.

\subsection{Pengujian Proctor.}

\subsubsection{Pengujian Berat Isi (Specific Gravity).}

Pengujian berat isi tanah bertujuan untuk mengetahui besar dari pada berat jenis butir tanah dalam keadaan padat. Berat isi dari suatu tanah juga mempengaruhi fungsi sebagai landasan dalam perhitungan mekanika tanah dalam uji pemadatan tanah. Berikut langkah langkah dalam pengujian berat isi :

1. Ukur tinggi dari cincin $(\mathrm{t})$ dan diameter cincin $(\mathrm{d})$.

2. Timbang berat cincin.

3. Olesi cincin dengan minyak bagian dalamnya dan masukkan tanah kedalam cincin.

4. Ratakanlah permukaannya dengan pisau atau spatula.

5. Timbang cincin beserta contoh tanah.

6. Hitung Volume.

7. Hitung Berat Jenis.

\subsubsection{Pengujian Pemadatan Tanah (Proctor).}

Pengujian Proctor bertujuan untuk mendapat nilai daya dukung tanah dalam keadaan padat maksimal. Berikut langkah - langkah pengujian pemadatan tanah :

1. Siapkan sampel uji sebanyak 4 sampel.

2. Pasang mold pada alas dan lehernya lalu timbang berat dan masukkan piring pemisah dengan alat pemisah diatasnya. 
3. Lakukan pemadatan sebanyak 3 lapisan dengan jumlah tumbukan $25 \mathrm{x} /$ lapis.

4. Lepaskan leher penyambung dan ratakan dengan pisau pemotong.

5. Balikkan moldnya serta pasang kembali, timbang beratnya.

6. Lakukan penetrasi dengan kecepatan 1,27 mm / menit (0.05).

7. Catatlah pembacaan dial pembebanan pada penetrasi.

8. Keluarkan sampel uji dengan menggunakan dongkrak, dan tentukan kadar airnya.

\section{Hasil dan Pembahasan}

\subsection{Uji Karakteristik Tanah}

Berdasarkan pengujian tanah yang telah dilakukan pada Laboratorium Teknik Sipil, Fakultas Teknik Universitas Kadiri, Kediri mengenai karakteristik tanah dari titik lokasi Jalan Demuk, Pucanglaban Kabupaten Tulungagung menggunakan metode gradasi ayakan didapati nilai data yang tercantum dalam Tabel 1 .

Tabel 1. Analisis Gradasi Butir Struktur Tanah Asli.

\begin{tabular}{|c|c|c|c|c|}
\hline \multirow{2}{*}{\multicolumn{2}{|c|}{ Jenis Partikel }} & \multirow{2}{*}{ Diameter $(\mathrm{mm})$} & \multicolumn{2}{|c|}{ Jumlah } \\
\hline & & & (gr) & $(\%)$ \\
\hline \multirow{6}{*}{ Kerikil (Gravel) } & Builders & $>256$ & \multirow{4}{*}{0} & \multirow{4}{*}{0} \\
\hline & Cobbles & $64-256$ & & \\
\hline & Pebbless & $4-64$ & & \\
\hline & Granules & $2-4$ & & \\
\hline & Very coarse sand & $1-2$ & 3 & 0,3 \\
\hline & Coarse sand & $0,5-1$ & 29 & 2,9 \\
\hline & Medium sand & $0,25-0,5$ & 40 & 4 \\
\hline \multirow[t]{2}{*}{ Pasir (Sand) } & Fine Sand & $0,125-0,25$ & 51 & 5,1 \\
\hline & Very fine Sand & $0,0625-0,125$ & 74 & 7,4 \\
\hline Lanau (Silt) & & $0,002-0,0624$ & 546 & 54,6 \\
\hline \multirow[t]{2}{*}{ Lempung (Clay) } & & $<0,002(M I C R O)$ & 257 & 25,7 \\
\hline & TOTAL & & 1000 & 100 \\
\hline
\end{tabular}

Sumber : Hasil Analisis Uji Gradasi Butir di Laboratorium Teknik Sipil Universitas Kadiri.

Dari Tabel 1. menunjukkan hasil dari persentase komulatif gradasi ayakan benda uji tanah yang diambil pada lokasi Jalan Demuk, Pucanglaban, Tulungagung dengan persentase lolos gradasi ayakan lebih kecil dari 200 (Micro) sebesar 25,7 sehingga menyimpulkan bahwa sebagian besar tanah dilokasi adalah lempung Ekspansif Montmorillonite.

\subsection{Pengujian Proctor.}

\subsubsection{Pengujian Berat Isi.}

Hasil dari pengujian berat isi tanah yang telah dikombinasikan bahan Additif Renolith dapat disajikan dalam Tabel 2. Berikut : 
Tabel 2. Berat Isi Mix Tanah Dan Renolith.

\begin{tabular}{cc}
\hline Bahan Additif Renolith $(\%)$ & Berat Isi $\left(\mathrm{gr} / \mathrm{cm}^{3}\right)$ \\
\hline 0 & 2,66 \\
5 & 2,59 \\
10 & 2,51 \\
15 & 2,44 \\
20 & 2,37
\end{tabular}

Sumber : Hasil Analisis Berat Isi di Laboratorium Teknik Sipil Universitas Kadiri.

Dari Tabel 2. Setelah benda uji dikombinasikan bahan Additif Renolith sejumlah 5\% dari berat total benda uji menjadi $2,59 \mathrm{gr} / \mathrm{cm}^{3}$, pada $10 \%$ senilai $2,51 \mathrm{gr} / \mathrm{cm}^{3}$, pada $15 \%$ adalah $2,44 \mathrm{gr} / \mathrm{cm}^{3}$ dan $20 \%$ senilai $2,37 \mathrm{gr} / \mathrm{cm}^{3}$.

\subsubsection{Pengujian Pemadatan Tanah.}

Hasil pengujian pemadatan dari variasi, disajikan pada Tabel 8. dengan melakukan perhitungan yang disajiakan pada Tabel 3., Tabel 4., Tabel 5., Tabel 6. dan Tabel 7.

Tabel 3 . Hasil Uji Pemadatan Tanah Struktur Tanah Asli.

\begin{tabular}{lcccc}
\hline \multicolumn{1}{c}{ Berat Uji (gr) } & 1 & 2 & 3 & 4 \\
\hline Berat Cetakan (gr) & 4502 & 4502 & 4502 & 4502 \\
Berat Tanah Basah + Cetakan & 6242 & 6286 & 6493 & 6511 \\
Berat Tanah Basah (W) & 1740 & 1784 & 1991 & 2009 \\
Berat Tanah Kering Oven (Ws) & 1641 & 1651 & 1810 & 1747 \\
$(\mathrm{Ww})=\mathrm{W}-\mathrm{Ws}$ & 99 & 133 & 181 & 262 \\
$(\mathrm{Wc})=\mathrm{Ww}: \mathrm{Ws} \mathrm{x} 100(\%)$ & 6,03 & 8,06 & 10,00 & 15,00 \\
$(\mathrm{~V})=\pi \cdot \mathrm{r}^{2} . \mathrm{t}(\mathrm{Cm})$ & 188,28 & 188,28 & 188,28 & 188,28 \\
$(\mathrm{ysat})=\mathrm{W}: \mathrm{V}\left(\mathrm{gr} / \mathrm{cm}^{3}\right)$ & 9,24 & 9,48 & 10,57 & 10,67 \\
$(\mathrm{yd})=\mathrm{Ws}: \mathrm{V}\left(\mathrm{gr} / \mathrm{cm}^{3}\right)$ & 8,72 & 8,77 & 9,61 & 9,28 \\
\hline
\end{tabular}

Sumber : Hasil Analisis Uji Pemadatan Tanah Benda Uji Tanah Asli di Laboratorium Teknik Sipil Universitas Kadiri.

Dari uji pemadatan tanah tanah asli yang telah dilakukan menunjukkan nilai berat volume kering terbesar adalah $9,61 \mathrm{gr} / \mathrm{cm}^{3}$, pada kadar air $10 \%$. 
Tabel 4. Hasil Uji Pemadatan Tanah Kombinasi Tanah Dengan 5\% Bahan Additif Renolith.

\begin{tabular}{lcccc}
\hline \multicolumn{1}{c}{ Berat Uji } & 1 & 2 & 3 & 4 \\
\hline Berat Cetakan & 4502 & 4502 & 4502 & 4502 \\
Berat Tanah Basah + Cetakan & 6300 & 6472 & 6665 & 6678 \\
Berat Tanah Basah (W) & 1798 & 1970 & 2163 & 2176 \\
Berat Tanah Kering Oven (Ws) & 1712 & 1823 & 1965 & 1891 \\
$(\mathrm{Ww})=\mathrm{W}-\mathrm{Ws}$ & 86 & 147 & 198 & 285 \\
$(\mathrm{Wc})=\mathrm{Ww}: \mathrm{Ws} \mathrm{x} 100(\%)$ & 5,02 & 8,06 & 10,08 & 15,07 \\
$(\mathrm{~V})=\pi \cdot \mathrm{r}^{2} . \mathrm{t}$ & 188,28 & 188,28 & 188,28 & 188,28 \\
$(\mathrm{ysat})=\mathrm{W}: \mathrm{V}\left(\mathrm{gr} / \mathrm{cm}^{3}\right)$ & 9,55 & 10,46 & 11,49 & 11,56 \\
$(\mathrm{yd}) \mathrm{Ws}: \mathrm{V}\left(\mathrm{gr} / \mathrm{cm}^{3}\right)$ & 9,09 & 9,68 & 10,44 & 10,04
\end{tabular}

Sumber : Hasil Analisis Uji Pemadatan Tanah Benda Uji Kombinasi Tanah dan 5\% Renolith di Laboratorium Teknik Sipil Universitas Kadiri.

Dari uji Pemadatan Tanah kombinasi tanah dengan 5\% bahan Additif Renolith yang telah dilakukan menunjukkan nilai berat volume kering terbesar adalah $10,44 \mathrm{gr} / \mathrm{cm}^{3}$, pada kadar air $10,08 \%$.

Tabel 5. Hasil Uji Pemadatan Tanah Kombinasi Tanah Dengan 10\% Bahan Additif Renolith.

\begin{tabular}{lcccc}
\hline \multicolumn{1}{c}{ Berat Uji } & 1 & 2 & 3 & 4 \\
\hline Berat Cetakan & 4502 & 4502 & 4502 & 4502 \\
Berat Tanah Basah + Cetakan & 6342 & 6534 & 6775 & 6801 \\
Berat Tanah Basah (W) & 1840 & 2032 & 2273 & 2299 \\
Berat Tanah Kering Oven (Ws) & 1752 & 1881 & 2066 & 1999 \\
$(\mathrm{Ww})=\mathrm{W}-\mathrm{Ws}$ & 88 & 151 & 207 & 300 \\
$(\mathrm{Wc})=\mathrm{Ww}: \mathrm{Ws} \mathrm{x} 100(\%)$ & 5,02 & 8,03 & 10,02 & 15,01 \\
$(\mathrm{~V})=\pi \cdot \mathrm{r}^{2} . \mathrm{t}$ & 188,28 & 188,28 & 188,28 & 188,28 \\
$(\mathrm{ysat})=\mathrm{W}: \mathrm{V}\left(\mathrm{gr} / \mathrm{cm}^{3}\right)$ & 9,77 & 10,79 & 12,07 & 12,21 \\
$(\mathrm{yd})=\mathrm{Ws}: \mathrm{V}\left(\mathrm{gr} / \mathrm{cm}^{3}\right)$ & 9,31 & 9,99 & 10,97 & 10,62 \\
\hline
\end{tabular}

Sumber : Hasil Analisis Uji Pemadatan Tanah Benda Uji Kombinasi Tanah dan 10\% Renolith di Laboratorium Teknik Sipil Universitas Kadiri.

Dari uji pemadatan tanah kombinasi tanah dengan 10\% bahan Additif Renolith yang telah dilakukan menunjukkan nilai berat volume kering terbesar adalah $10,97 \mathrm{gr} / \mathrm{cm}^{3}$, pada kadar air $10,02 \%$. 
Tabel 6. Hasil Uji Pemadatan Tanah Kombinasi Tanah Dengan 15\% Bahan Additif Renolith.

\begin{tabular}{lcccc}
\hline \multicolumn{1}{c}{ Berat Uji } & 1 & 2 & 3 & 4 \\
\hline Berat Cetakan & 4502 & 4502 & 4502 & 4502 \\
Berat Tanah Basah + Cetakan & 6432 & 6675 & 6895 & 6922 \\
Berat Tanah Basah (W) & 1930 & 2173 & 2393 & 2420 \\
Berat Tanah Kering Oven (Ws) & 1838 & 2012 & 2175 & 2104 \\
$(\mathrm{Ww})=\mathrm{W}-\mathrm{Ws}$ & 92 & 161 & 218 & 316 \\
$(\mathrm{Wc})=\mathrm{Ww}: \mathrm{Ws} \mathrm{x} 100(\%)$ & 5,01 & 8,00 & 10,02 & 15,02 \\
$(\mathrm{~V})=\pi \cdot \mathrm{r}^{2} \cdot \mathrm{t}$ & 188,28 & 188,28 & 188,28 & 188,28 \\
$(\mathrm{ysat})=\mathrm{W}: \mathrm{V}\left(\mathrm{gr} / \mathrm{cm}^{3}\right)$ & 10,25 & 11,54 & 12,71 & 12,85 \\
$(\mathrm{yd})=\mathrm{Ws}: \mathrm{V}\left(\mathrm{gr} / \mathrm{cm}^{3}\right)$ & 9,76 & 10,69 & 11,55 & 11,17 \\
\hline
\end{tabular}

Sumber : Hasil Analisis Uji Pemadatan Tanah Benda Uji Kombinasi Tanah dan 15\% Renolith di Laboratorium Teknik Sipil Universitas Kadiri.

Dari uji pemadatan tanah kombinasi tanah dengan 15\% bahan Additif Renolith yang telah dilakukan menunjukkan nilai berat volume kering terbesar adalah $11,55 \mathrm{gr} / \mathrm{cm}^{3}$, pada kadar air 10,08\%.

Tabel 7. Hasil Uji Pemadatan Tanah Kombinasi Tanah Dengan 20\% Bahan Additif Renolith.

\begin{tabular}{|c|c|c|c|c|}
\hline Berat Uji (gr) & 1 & 2 & 3 & 4 \\
\hline Berat Cetakan & 4502 & 4502 & 4502 & 4502 \\
\hline Berat Tanah Basah + Cetakan & 6501 & 6710 & 6940 & 6950 \\
\hline Berat Tanah Basah (W) & 1999 & 2208 & 2438 & 2448 \\
\hline Berat Tanah Kering Oven (Ws) & 1904 & 2044 & 2216 & 2129 \\
\hline Berat Air $(\mathrm{Ww})=\mathrm{W}-\mathrm{Ws}$ & 95 & 164 & 222 & 319 \\
\hline $\mathrm{Wc}=\mathrm{Ww}: \mathrm{Ws} \times 100(\%)$ & 4,99 & 8,02 & 10,02 & 14,98 \\
\hline $\operatorname{ISI}$ CETAKAN $(\mathrm{V})=\pi \cdot \mathrm{r}^{2} . \mathrm{t}(\mathrm{mm})$ & 188,28 & 188,28 & 188,28 & 188,28 \\
\hline ysat = W : V $\left(\mathrm{gr} / \mathrm{cm}^{3}\right)$ & 10,62 & 11,73 & 12,95 & 13,00 \\
\hline$\gamma \mathrm{d}=\mathrm{Ws}: \mathrm{V}\left(\mathrm{gr} / \mathrm{cm}^{3}\right)$ & 10,11 & 10,86 & 11,77 & 11,31 \\
\hline
\end{tabular}

Sumber : Hasil Analisis Uji Pemadatan Tanah Benda Uji Kombinasi Tanah dan 20\% Renolith di Laboratorium Teknik Sipil Universitas Kadiri.

Dari uji pemadatan tanah kombinasi tanah dengan 20\% bahan Additif Renolith yang telah dilakukan menunjukkan nilai berat volume kering terbesar adalah $11,77 \mathrm{gr} / \mathrm{cm}^{3}$, pada kadar air 10,02\%. 


\subsection{Rekapitulasi Data.}

Dari penelitian dan perhitungan uji pemadatan tanah dari beberapa benda uji didapatkan hasil grafik yang telah disajikan pada Gambar 1.

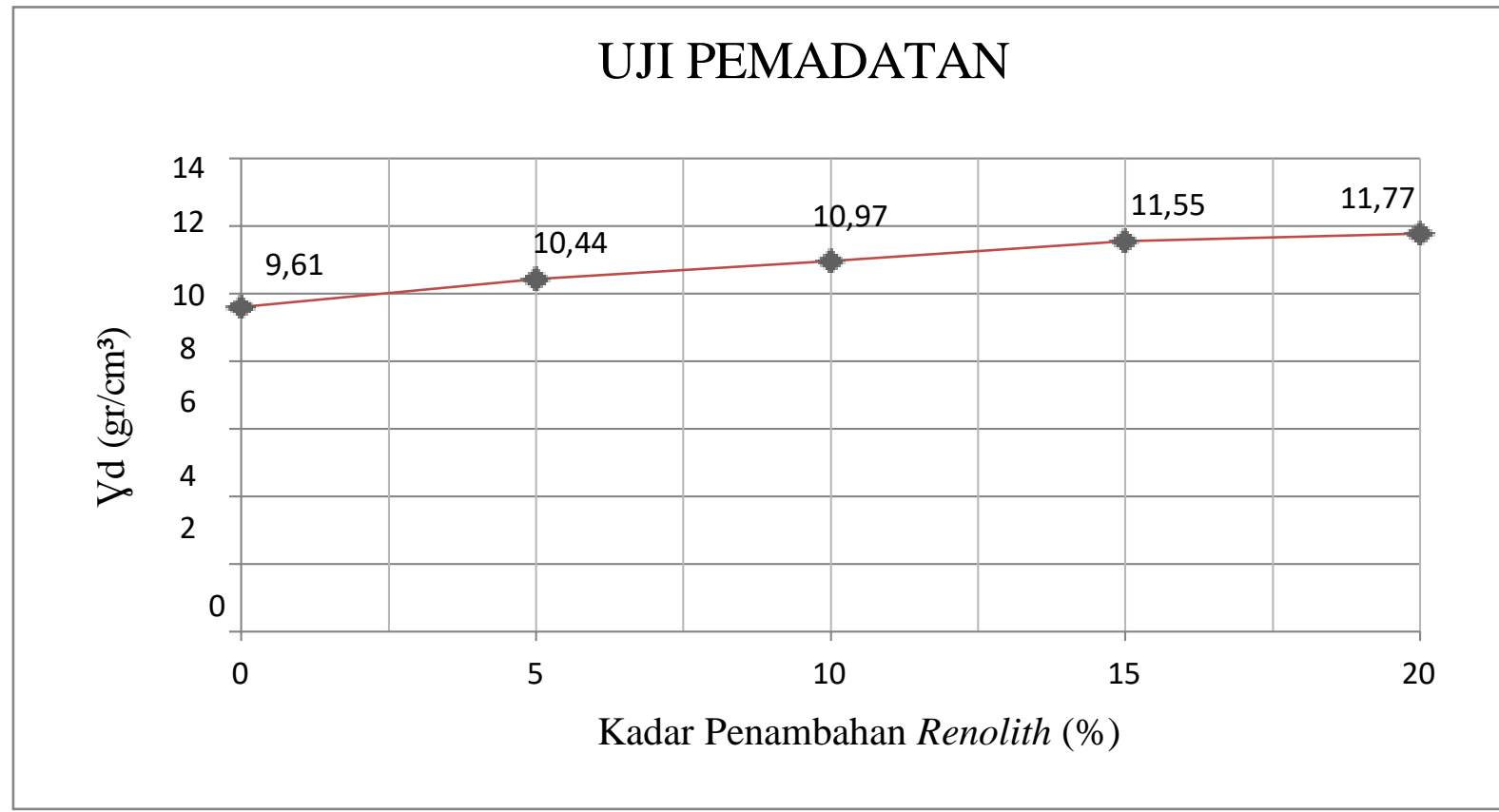

Sumber : Hasil Analisis Pemadatan Tanah Keseluruhan Benda Uji Kombinasi Tanah dan Renolith di Laboratorium Teknik Sipil Universitas Kadiri.

Gambar 1. Grafik Hasil Uji pemadatan Tanah Dari Keseluruhan Benda Uji.

Dalam konteks keseragaman kadar air, Penambahan air sebesar (Mendekati) 10\% dari berat benda uji dengan tingkat pemadatan yang sama, Kombinasi Bahan Additif Renolith sebanyak 0\% (Struktur Tanah Asli) menunjukkan berat volume kering benda uji setelah dilakukan uji pemadatan sebesar 9,61 gr/ $\mathrm{cm}^{3}$. Kombinasi Bahan Additif Renolith sebanyak 5\% berat volume kering 10,44 $\mathrm{gr} / \mathrm{cm}^{3}, 10 \%$ adalah $10,97 \mathrm{gr} / \mathrm{cm}^{3}, 15 \%$ adalah $11,55 \mathrm{gr} / \mathrm{cm}^{3}$ dan penambahan Renolith sebanyak $20 \%$ menghasilkan berat volume kering sebesar $11,77 \mathrm{gr} / \mathrm{cm}^{3}$.

Tabel 8. Hasil Konversi Uji Pemadatan Tanah Dengan Berat Isi.

\begin{tabular}{cccc}
\hline \multirow{2}{*}{ Renolith } & Nilai Pemadatan Tanah & Berat Isi & Hasil Proctor $(\mathrm{C} \mathrm{:} \mathrm{Bj)}$ \\
\cline { 2 - 4 } & $(\mathrm{\gamma d})$ & $(\mathrm{Bj})$ & $\mathrm{gr} / \mathrm{cm}^{3}$ \\
\hline 0 & 9,61 & 2,66 & 3,61 \\
5 & 10,44 & 2,55 & 4,09 \\
10 & 10,97 & 2,51 & 4,37 \\
15 & 11,55 & 2,44 & 4,73 \\
20 & 11,77 & 2,37 & 4,97 \\
\hline
\end{tabular}

Sumber : Hasil Konversi Uji Pemadatan Tanah dengan Berat Jenis Benda Uji Kombinasi Tanah dan Renolith di Laboratorium Teknik Sipil Universitas Kadiri. 
Nilai yang ditunjukkan pada perhitungan tersebut adalah ketika benda uji struktur tanah asli memiliki berat volume kering ( $\mathrm{\gamma d}$ ) sebesar 3,61, pada struktur tanah asli yang dikombinasikan Renolith sejumlah 5\% menunjukkan nilai berat volume kering (yd) sebesar $4,03 \mathrm{gr} / \mathrm{cm}^{3}$, pada kombinasi sejumlah $10 \%$ adalah sebesar $3,36 \mathrm{gr} / \mathrm{cm}^{3}$, pada kombinasi sejumlah $15 \%$ sebesar $4,73 \mathrm{gr} / \mathrm{cm}^{3}$ dan pada kombinasi $20 \%$ adalah sebesar $4,97 \mathrm{gr} / \mathrm{cm}^{3}$.

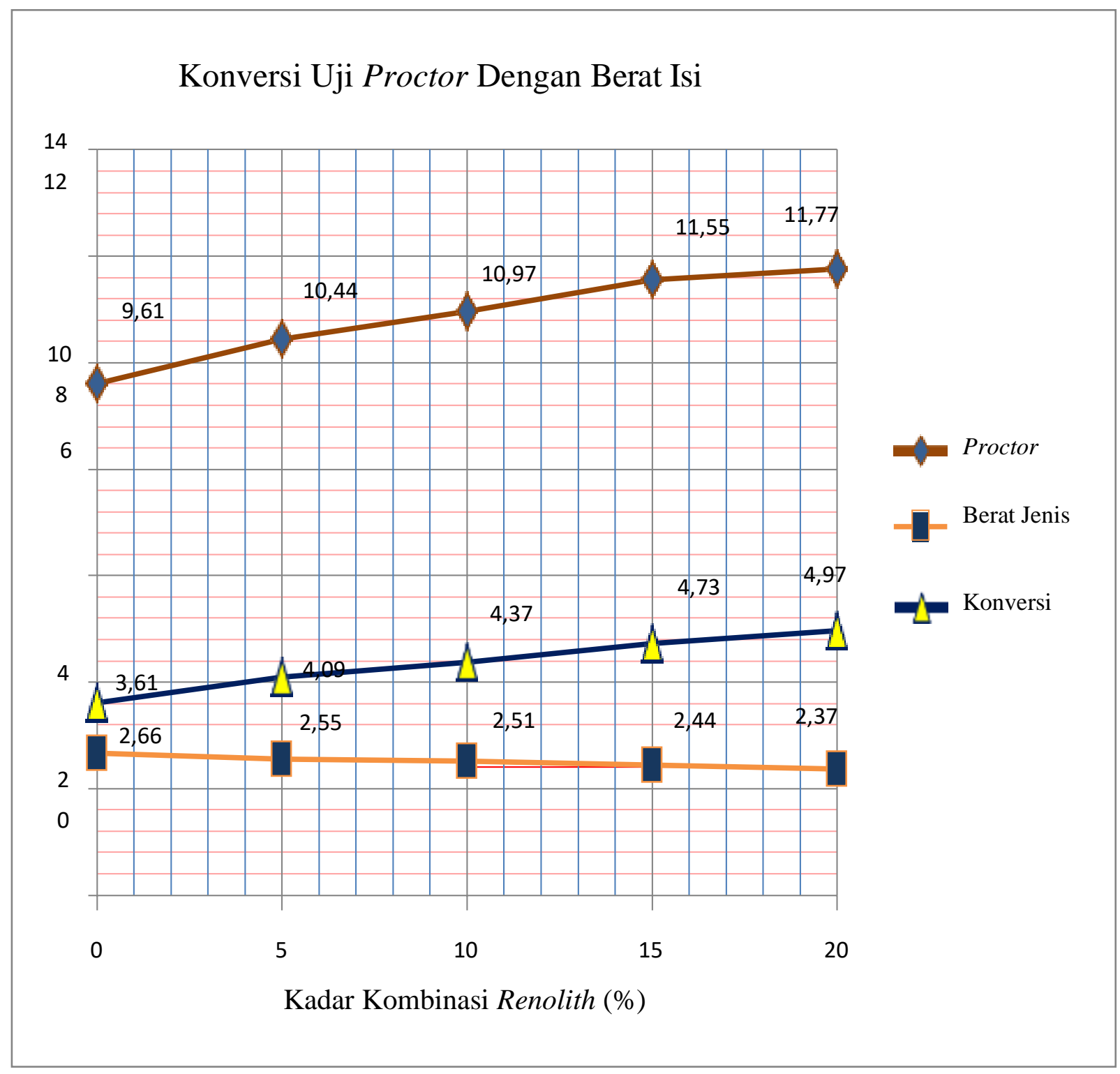

Sumber : Hasil Konversi Uji Proctor dengan Berat Isi Benda Uji Kombinasi Tanah dan Renolith di Laboratorium Teknik Sipil Universitas Kadiri.

Gambar 2. Grafik Hasil Konversi Uji Proctor Pemadatan Tanah Dengan Berat Isi

Grafik pada Gambar 2. Menunjukkan bahwa kombinasi bahan Additif Renolith sejumlah 20\% pada nilai konversi perhitungan Uji Proctor dengan berat isi merupakan jumlah terbesar pengujian pemadatan tanah. 


\section{Kesimpulan dan Saran}

\subsection{Kesimpulan}

Berdasarkan hasil pengujian dan pembahasan yang telah diuraikan sebelumnya maka dapat ditarik kesimpulan sebagai berikut :

1. Sebagian besar tanah dilokasi Jalan Demuk, Pucanglaban, Tulungagung adalah lempung Ekspansif Montmorillonite. Hal tersebut ditunjukkan dari persentase komulatif gradasi ayakan lolos yang lebih kecil dari 200 (Micro) sebesar 25,7\%.

2. Pada pengujian Proctor benda uji struktur tanah asli memiliki berat volume kering ( $\mathrm{\gamma d}$ ) sebesar 3,61, setelah dikombinasikan renolith sejumlah 5\% menunjukkan nilai berat volume kering ( $\mathrm{\gamma d}$ ) sebesar 4,03 gr/cm3, pada kombinasi sejumlah $10 \%$ adalah sebesar 3,36 gr/cm3, pada kombinasi sejumlah $15 \%$ sebesar $4,73 \mathrm{gr} / \mathrm{cm} 3$ dan pada kombinasi $20 \%$ adalah sebesar 4,97 gr/cm3. Semakin besar jumlah kombinasi bahan additif renolith nilai berat volume kering juga mengalami peningkatan, dengan demikian dapat disimpulkan bahwa masalah stabilitas tanah dilokasi pengujian dapat diatasi dengan melakukan kombinasi bahan additif renolith.

\subsection{Saran}

Perbaikan tanah pada suatu titik lokasi lain harus melewati beberapa perhitungan lebih lanjut sesuai dengan konteks kebutuhan lapangan meliputi asumsi kebutuhan Bahan additif renolith dan uji jenis tanah yang akan stabilkan. Hal tersebut dikarenakan pada setiap titik area maupun lokasi, kebutuhan lapangan dan struktur tanah berbeda - beda. 


\section{Daftar Pustaka}

[1] A. I. Candra, "STUDI KASUS STABILITAS STRUKTUR TANAH LEMPUNG PADA JALAN TOTOK KEROT KEDIRI MENGGUNAKAN LIMBAH KERTAS,” UKaRsT, vol. 2, no. 2, p. 11, 2018, doi: 10.30737/ukarst.v2i2.255.

[2] H. Wahyudiono, "PERENCANAAN PONDASI BORE PILE PADA PROYEK JEMBATAN NGUJANG II KAB.TULUNGAGUNG," UKaRsT, vol. 2, no. 1, 2018, doi: 10.30737/ukarst.v2i1.356.

[3] S. Schlecht-Pietsch, U. Wagner, and T. H. Anderson, "Changes in composition of soil polysaccharides and aggregate stability after carbon amendments to different textured soils," Appl. Soil Ecol., vol. 1, no. 2, pp. 145-154, 1994, doi: 10.1016/09291393(94)90034-5.

[4] A. I. Candra, "Pada Pembangunan Gedung Mini Hospital Universitas Kadiri," Ukarst, vol. 1, no. 1, pp. 63-70, 2017.

[5] H. Widhiarto, A. H. Andriawan, A. Matulessy, F. Teknik, and F. Psikologi, "STABILISASI TANAH LEMPUNG EKSPANSIF DENGAN MENGGUNAKAN CAMPURAN ABU-SEKAM DAN KAPUR,” J. Pengabdi. Masy., vol. 01, no. 02, pp. 135-140, 2015.

[6] S. Son, T. Maeda, S. Ueda, F. Kanamaru, and M. Koizumi, "Synthesis of Cu(II)-TCNQ complex on the interlamella surfaces of montmorillonite," J. Inorg. Nucl. Chem., vol. 42, no. 3, pp. 367-370, 1980, doi: 10.1016/0022-1902(80)80008-X.

[7] A. Susanto, "PENGARUH STABILISASI TANAH LEMPUNG DENGAN ASPAL EMULSI Klasifikasi tanah," KoNTekS 3, 2009.

[8] N. Kholis, A. S. Srie Gunarti, and R. Sylviana, "Stabilisasi Tanah Lempung Menggunakan Semen dan Renolith," BENTANG J. Teor. dan Terap. Bid. Rekayasa Sipil, vol. 6, no. 1, pp. 62-77, 2018, doi: 10.33558/bentang.v6i1.535.

[9] Das Braja M, "Mekanika Tanah (Prinsip-Prinsip Rekayasa Geoteknis) Jilid 1," Erlangga, 1985.

[10] H. A 'la, B. Setiawan, and N. Djarwanti, "Penambahan Limbah Plastik Pada Tanah Ekspansif,” Matriks Tek. Sipil, 2017.

[11] S. Gunarti and A. Setyowati, "Daya Dukung Tanah Lempung Yang Distabilisasi Dengan Spent Catalyst Rec 15 Dan Kapur," Bentang, vol. 2, no. 1, 2014. 
[12] R. Syiko, “Analisis Resiko Bencana Sebelum dan Setelah Letusan Gunung Kelud Tahun 2014 ( Studi kasus di Kecamatan Ngantang , Malang ) Disaster Risk Assessment of Kelud Vulcano , Before and After Eruption in 2014 ( Study case of Ngantang Subdistrict , Malang , Indone," J-Pal, vol. 5, no. 2, pp. 22-29, 2014.

[13] J. A. Coblinski, É. Giasson, J. A. M. Demattê, A. C. Dotto, J. J. F. Costa, and R. Vašát, "Prediction of soil texture classes through different wavelength regions of reflectance spectroscopy at various soil depths," Catena, vol. 189, no. January, 2020, doi: 10.1016/j.catena.2020.104485.

[14] Z. Mubarok, K. Murtilaksono, and E. D. Wahjunie, "Response of Landuse Change on Hydrological Characteristics of Way Betung Watershed - Lampung," J. Penelit. Kehutan. Wallacea, vol. 4, no. 1, p. 1, 2015, doi: 10.18330/jwallacea.2015.vol4iss1pp110.

[15] H. Palar, S. Monintja, A. . Turangan, and A. . Sarajar, "Pengaruh pencampuran tras dan kapur pada lempung ekspansif terhadap nilai daya dukung," J. Sipil Statik, vol. 1, no. 6, pp. 390-399, 2013.

[16] A. Kumar and P. Lingfa, "Sodium bentonite and kaolin clays: Comparative study on their FT-IR, XRF, and XRD," Mater. Today Proc., vol. 22, no. xxxx, pp. 737-742, 2020, doi: 10.1016/j.matpr.2019.10.037.

[17] Berty Sompie and T. Ilyas, "Pengaruh Proses Konsolidasi Terhadap Deformasi Dan Faktor Keamanan Lereng Embankment (Studi Kasus Bendungan Kosinggolan)," Stud. Magister Tek. Sipil, Univ. Udayana, Bali, Indones., 2015.

[18] T. Karl and R. B. Peck, "Mekanika Tanah dalam Praktek Rekayasa," Jakarta: Erlangga, 1987.

[19] E. Gardjito, A. I. Candra, and Y. Cahyo, "Pengaruh Penambahan Batu Karang Sebagai Substitusi Agregat Halus Dalampembuatan Paving Block," UKaRsT, vol. 2, no. 1, p. 35, 2018, doi: 10.30737/ukarst.v2i1.374.

[20] C. Chomaedhi, M. Khoiri, and M. Machsus, "Kajian Tanah Ekspansif, Jalan Akses Jembatan Suramadu Sisi Madura,” J. Apl. Tek. Sipil, vol. 3, no. 1, p. 11, 2007, doi: 10.12962/j12345678.v3i1.2563.

[21] A. I. Candra, E. Gardjito, Y. Cahyo, and G. A. Prasetyo, "Pemanfaatan Limbah Puntung Rokok Filter Sebagai Bahan Campuran Beton Ringan Berpori," UKaRsT, vol. 3, no. 1, 
p. 82, 2019, doi: 10.30737/ukarst.v3i1.365.

[22] Sutikno and B. Damianto, "Stabilisasi Tanah Ekspansif Dengan Penambahan Kapur (Lime): Aplikasi Pada Pekerjaan Timbunan,” J. Tek. Sipil dan Perenc., vol. 11, no. 2, pp. 101-108, 2009.

[23] A. Prabowo and M. Fauziah, "PENGARUH STABILISASI TANAH MENGGUNAKAN KAPUR DAN MATOS TERHADAP KUAT GESER DAN KONSOLIDASI TANAH GAMBUT,” Dsp. UII, 2018.

[24] M. S. Wahyu Setyaningsih, "Pemetaan daerah rawan bencana gerakan tanah di wilayah grabag kabupaten magelang propinsi jawa tengah,” Geogr. Inf. Syst., vol. 8, no. 1, pp. 1$8,2010$.

[25] Y. Zhang, Q. Zhen, Y. Cui, P. Zhang, and X. Zhang, "Use of montmorillonite-enriched siltstone for improving water condition and plant growth in sandy soil," Ecol. Eng., vol. 145, no. 26, p. 105740, 2020, doi: 10.1016/j.ecoleng.2020.105740.

[26] G. MAULANA and I. N. HAMDHAN, "Stabilisasi Tanah Lempung Ekspansif Menggunakan Campuran Renolith dan Kapur," Reka Racana J. Online Inst. Teknol. Nas., vol. 2, no. 4, pp. 11-21, 2016.

[27] O. O. Ojuri, A. A. Adavi, and O. E. Oluwatuyi, "Geotechnical and environmental evaluation of lime-cement stabilized soil-mine tailing mixtures for highway construction," Transp. Geotech., vol. 10, pp. 1-12, 2017, doi: 10.1016/j.trgeo.2016.10.001.

[28] F. yan Meng, R. peng Chen, and X. Kang, "Effects of tunneling-induced soil disturbance on the post-construction settlement in structured soft soils," Tunn. Undergr. Sp. Technol., vol. 80, no. September 2017, pp. 53-63, 2018, doi: 10.1016/j.tust.2018.06.007.

[29] Z. Ai-jun, M. Hai-hong, and Z. Zhen-de, “Theoretical Elastio-Plastic Solution for Piles Subject to Lateral Soil Movement," Procedia Earth Planet. Sci., vol. 5, no. 2011, pp. 58-63, 2012, doi: 10.1016/j.proeps.2012.01.010. 